\title{
BHĀVIVEKA VS. CANDRĀNANDA
}

\author{
HUANHUAN HE \\ School of Humanities, Zhejiang University \\ No. 148 Tianmushan, Hangzhou, China 310028 \\ e-mail:pkuhhh@gmail.com
}

This essay offers an analysis of "the two-finger" illustration which Bhāviveka discusses in the Vaiśșikatattvaviniścaya chapter of the Tarkajvālā, the auto-commentary on his Madhyamakahrda$y a[k \bar{a} r i k \bar{a}]$, wherein he introduces and criticises the theories of the Vaiśeșika school. Going through the early Vaiśeșika literature, I have noticed that these two-finger (dvyangula, two fingers in a unit form, or finger-pair) illustrations only occur in Candrānanda's Vrtti, and in a very clear and straightforward manner. As I will point out, it is a mystery and indeed somewhat perplexing that the references to this illustration in the Tarkajvāla are not at all immediately intelligible. This circumstance will be addressed in this essay, where also an interpretation and a solution will be offered. In addition, the relative chronology of Bhāviveka and Candrānanda as well as their contemporaries in around 6th-century India will also be discussed.

Key words: Bhāviveka, Candrānanda, Tarkajvālā, Candrānandavrtti, dvyañgula, two-finger illustration.

\section{Preliminaries}

The study of the confrontation of the Indian Buddhist schools of thought with other Indian philosophical traditions such as Sāṃkhya, Vaiśeșika, Nyāya, Mīmāṃsa and Vedānta has had a long history. In spite of this, many of its details are still unclear and thus still await resolution. As is well known, the polemical writings of the 6th-century Madhyamaka-Buddhist intellectual Bhāviveka provide an excellent point of departure for such studies. An inquiry into the sources with which he was working will further our understanding of this important scholar's intellectual biography. It is also relevant for the much larger issues that bear on India's intellectual history as such. In addition, Bhāviveka's encounter with these other traditions has a direct bearing on the way in which his oeuvre should be studied and understood. It is of course true 
that a fair number of in-depth discussions of issues relating to Bhāviveka's place in Indian intellectual history have already been published. But there is still much to be done. That being said, it goes without saying that we all build on the results obtained by our precursors and my present essay is certainly no exception.

For my present purpose, I will not deal with Bhāviveka's understanding of Vaiśeșika philosophy as discussed in his *Hastaratna, which is only available in the Chinese translation by Xuanzang 玄牀 (600/602-664), the Dasheng zhangzhen lun 大乘掌珍論, and his Prajñāpradīpa commentary on Nāgārjuna's (2nd century) Mūlamadhyamakakārikā. This will be reserved for another occasion. ${ }^{1}$ I propose here to examine "the two-finger" (dvyañgula) illustration which Bhāviveka mentions in the Vaiśeșikatattvaviniścaya chapter of his Tarkajvālā [hereafter TJ-V]. Only extant in a Tibetan translation, the latter is the auto-commentary on his seminal Madhyamakahrdaya [hereafter MH-V] which is available in Sanskrit and in a Tibetan translation. Reading through the early Vaiśeșika literature, the Vaiśeșikasūtra and its commentaries such as the Candrānandavrtti, Padārthadharmasamgraha, etc., I noticed that this illustration only occurred in Candrānanda's Vrtti-commentary on the Vaiśeșikasütra and that it did so several times and in a very lucid and unambiguous manner. This has led me to re-examine the data on which basis some tentative conclusions were reached; they add additional pieces to the puzzle of the relative chronology of Candrānanda and Bhāviveka, pieces that, I believe, have so far not played an adequate role in the various proposals known to me. ${ }^{2}$

Not as "well known" (kīrti) as the Madhyamaka philosopher Candrakīrti (6th century), but "delightful" (ānanda) in his own way, Candrānanda is the author of the earliest commentary on the Vaiśeșikasutra that has come down to us. His work is thus called the Candrānandavrtti [hereafter CV]. There, his name is a śleșa-like part of its closing verse reading as follows (Jambuvijaya 1961, p. 76):

jagato 'syānandakaram vidyāsavayā $h^{3}$ sadaiva yaś candram / ānandayati sa vrttị̣ candrānando vyadhād etām //

Candrānanda, who continuously pleases the moon bringing pleasure to the world being his friend in knowledge, created this commentary.

${ }^{1}$ Among the latest discussions of Bhāviveka's oeuvre with rather informative bibliographies are Heitmann (2004, pp. xv-xviii), Saitō (2005, pp. 167-173), Eckel (2008, pp. 17-27), Krasser (2011, pp. 49-76) and (2012, pp. 535-594), and He-van der Kuijp (2014). In addition, Nishikawa (1983) deals with the Vaiśeșika school's theory of time $(k \bar{a} l a)$ in the nineteenth chapter of the Prajñāpradīpa in detail.

${ }^{2}$ I very briefly discussed the possible relative chronology of Candrānanda and Bhāviveka in He (2011; and 2013, pp. 150-152).

${ }^{3}$ Jambuvijaya's edition reads vidyāśarvaryā, while vidyāsavayāh is suggested by Ruzsa (2004/2012, p. 89), since the former is metrically impossible (two morae long). Accordingly, the text could be translated as follows: "Candrānanda, who rejoiced in the moon bringing pleasure to the world at all times in the bright starry night, created this commentary." 
Muni Śrī Punyavijaya was probably the first to have recovered the Sanskrit manuscript of the Candrānandavrtti in the Jaisalmer Bhandar, in around 1874. In his 1917 dissertation, H. Ui wrote that "Candrananda's [sic] Bhāsya is said by L. F. Kielhorn to be complete" (Ui 1917, p. 13). He never mentioned the Candrānandavrtti in his later works, so that I take this to indicate that while he knew of its existence, he unfortunately never gained access to it. In fact, the Jaina monk Jambuvijaya's 1961 (second edition in 1982) outstanding publication of the Candrānandavrtti was the very first critical edition based on two complete Sanskrit manuscripts: (1) the text of the Punyavijaya's collection of manuscripts that are now preserved in the L. D. Institute of Ahmedabad, in Jaina Devanāgarī script, transcribed in around the 13th or 14th century; and (2) the manuscript under no. 1831(h) of the collection in the Oriental Institute, Baroda, in Sāradā script. The date on which it was copied is not given, but A. Thakur suggested that it was not very old. ${ }^{4}$ It is because of Jambuvijaya's labours that Candrānanda's name and his Vrtti spread throughout the realm of Indological scholarship. E. Frauwallner remarked with unreserved praise in his 1962 review that Jambuvijaya's edition of the text must be used in all future work on the early Vaiśeșika. In 2012 (prepared in 2004), F. Ruzsa uploaded an "unfinished work" to the website academia.edu, Candrānanda's Commentary on the Vaiśeșika-Sütra, which is a critical version of the text that is based on a collation of all manuscripts known to him, namely, all the manuscripts $H$. Isaacson has used, i.e. all the five manuscripts that are known to date (Ruzsa 2004/2012).

${ }^{4}$ See A. Thakur's introduction in Jambuvijaya (1961, p. 1). Furthermore, Isaacson (1995, pp. 146-147) reported the existence of three other paper manuscripts of the Candrandavrtti: (1) a manuscript in the Bhandarkar Oriental Research Institute, no. 99 of 1873-1874, Jaina Devanāgarī script, 20 folios, copied in 1874 A.D.; (2) a manuscript in the Bhandarkar Oriental Research Institute, no. 503 of 1875-1876, Śāradā script, 33 folios, undated; (3) a manuscript in the Scindia Oriental Institute, Ujjain, no. 4635, Śāradā script, probably copied in 1888 A.D. These three manuscripts were not used by Jambuvijaya. For the relationship among these manuscripts, see Isaacson (1995, pp. 148-151) and Ruzsa (2010).

Frauwallner (1962). Isaacson (1995, p. 143, n. 13) rightly pointed out that: "Unfortunately, even more than a quarter-century after the publication of Jambuvijaya's edition, articles and books continue to appear which base their statements and conclusions about the early Vaiśeșika on the text of the Vaiśeșikasütra as commented on by Śankkara Miśra, and do not refer to, or even appear to be aware of, Candrānanda's commentary and the sūtrapātha it contains. A striking example is formed by a book by Veena Gajendragadkar, Kanāäda's Doctrine of the Padārthas i.e. the Categories, Delhi, 1988." The situation is better since Isaacson's writing, but there is still only one translation of the entire Candrāndavrtti, namely, the Japanese translation in Miyamoto (2009), and several partial English translations in Isaacson (1990: CV ad vs 3.1.13, 3.2.1, 4.1.6 14, and Adhyāya 8), Nozawa (1993: Adhyāya 1 and Adhyāya 2), Halbfass (1992: CV ad vs 1.2.1 18, 9.1 12), and Thakur (2003, selected translation, pp. 24-121). Kanakura (1971, pp. 47-94) translated all the sūtrapāthas from the Candrāndavrtti into Japanese while only using the Vrtti for references. Nakamura (19771978 ) also referred to it while translating the Vaiśeșikasūtra into Japanese. It is said that M. Nozawa made a full English translation of it for his M. Phil. thesis which he submitted to the Department of Sanskrit of Madras University, but I have not been able to see this unpublished thesis. The Ph.D. dissertation of Isaacson (1995) contains only a critical Sanskrit edition of the first chapter (i.e. Adhyāya $1, \bar{A}$ hnika $1 \& 2$ ) and half of the second chapter (i.e. Adhyāya 2, Āhnika 1) with translations of but very few pieces. I have prepared a Chinese translation of the entire text, which will be published in 2017 with Zhejiang University Press, Hangzhou. 
Although much effort has been expended on this important Vaiśeșika scholar and his Vrtti, nothing is really known aside from his name "Candrānanda". We do not know when Candrānanda may have lived, but there is one single hint that has drawn the attention of many scholars, namely, that Candrānanda quoted Nyāyavārttika, 1.1.10, together with mentioning the author's name Uddyotakara, in CV ad Vs 3.2.4. ${ }^{6}$ If we take at face value an Indian tradition asserted by Dharmottara (late 8th century) to the effect that the famous Naiyāyika intellectual Uddyotakara was a contemporary of Dharmakīti, who himself may have flourished in the 6th or 7th century (see Steinkellner 1979, p. 39, note 93), then it is reasonable to hold that Candrānanda should be posterior to him. In addition, Candrānanda mentions a mysterious Vṛttikāra in the ninth chapter twice, but his identity has yet to be ascertained.?

With regard to Candrānanda's date, B. J. Sandesara wrote in the foreword to Jambuvijaya's edition that "this commentary must have been written sometime after the 6th century, very probably during the 7th century" (Jambuvijaya 1961, p. viii). In the introduction to this same edition, A. Thakur argued that "Candrānanda's Vrtti did not receive the circulation it deserves and we find no mention of him in the later Vaiśeșika literature" (Jambuvijaya 1961, p. 23). ${ }^{8}$ Subsequently, in his paper on Candrānanda's date, A. Aklujkar pointed out that suttrapāthas of CV ad Vs 2.2.14, 2.2.16, 2.2.17, and 2.2.18 are obviously quoted by the famous philosopher and poet Helārāja (10th century) in his commentary on Bhartrtari's (6th century) Vākyapadìya. Thus he concluded that Candrānanda flourished somewhere between the 5th/6th and the 10th centuries (Aklujkar 1970, p. 340). ${ }^{9}$ This long period is somewhat unhelpful, if not meaningless. K. H. Potter ranked Candrānanda among a group of "a few undatable writers", and suggested that he flourished sometime between the 7th and the 14th or 15 th centuries. ${ }^{10} \mathrm{H}$. Isaacson, one of the latest authors to have carefully studied the Candrānandavrtti, stated in agreement with Chemparathy that "judging from the

${ }^{6} \mathrm{CV}$ ad Vs 3.2.4: devadattasya rūparasagandhasparśapratyayā ekānekanimittāh mayeti pratyayena pratisandhānāt krtasan்ketānām bahūnām ekasmin nartakībhrūkșepe yugapad anekapratyayavat iti uddyotakarah/. The text of the Candrannandavrtti (vS-C, CV ad vs) that is taken from Jambuvijaya (1961) is numbered according to the sütrapatthas, so that I will not repeat the page numbers of Jambuvijaya (1961). See also Nyāyavārttika, 1.1.10: devadattasya rūparasasparśapratyayāh ekānekanimittāh smrtyā saha mayeti pratisandhānāt krtasañketānām bahūnām ekasmin nartakībhrūkșepe yugapad anekapratyayavat/; cf. Tarkatirtha(s) (1982, p. 192) and Jhā (1983, p. 231).

${ }^{7} \mathrm{CV}$ ad vs 9.18: tatra evamvidhaprasiddhasambandhasyārthaikadeśam asandigdham paśyatah śesānuvyavasāyo yah sa lingadarśanāt sañjāyamāno laingikam iti vrttikārah/; CV ad vs 9.21: yathā abhinayāder api artham pratipadyante laukikā evam śabdo 'rthasya sañketavaśena vyañjakatvāt kāraṇam iti vrttikärah/. Matilal (1977, p. 75) suggested that these two Vrttikäras are also Uddyotakara. p. 131)

${ }^{8}$ A. Thakur did not give any date for Candrānanda in his latest work, see Thakur (2003,

${ }^{9}$ Nozawa (1993, p. 97) agreed with Aklujkar that "the lower limit of Candrānanda's date is fixed as the 10th century when Helārāja is supposed to have flourished".

${ }^{10}$ Potter (1977, p. 685) wrote: "Finally, we come to Candrānanda. His Vrtti on the Vaiśesikasütras is now available, but estimates of his date differ widely. Sandesara suggests the 7 th century, but M. Hattori thinks it is much later, possible after our period altogether." Although Hattori (1966 and 1994) did use the Candrānandavrtti, Potter (1977) did not provide a source for M. Hattori's speculation and I did not find any publication where M. Hattori discussed Candrānanda's date. 
contents and the style of his work I feel strongly inclined to place this commentary before the 10th century, probably in the 7th or 8th century, this latter precision being hypothetical" (Isaacson 1995, p. 141; Chemparathy 1970, p. 48). K. Miyamoto, the Japanese translator of the entire Sanskrit text of Jambuvijaya's 1961 edition considered that the Candrānandavrtti was composed in the 7th century (Miyamoto 2009, p. 3). And, finally, W. Halbfass suggested its date to around 900 (Halbfass 1992, p. 237). This should suffice. There is no need to add further speculations on Candrānanda's date; there is no hard evidence for his terminus ante quem. But the evidence of his knowledge of Uddyotakara does suggest that his terminus post quem would fall in the 6 th or 7 th century.

\section{The Two-finger Illustration}

\subsection{The Two-finger Illustration in the Introductory Portion of the Tarkajvālā's Vaiśeșika Chapter}

Bhāviveka appears to be the very first Buddhist intellectual to have very systematically criticised the Vaiśeșika in the seventh chapter of his Madhyamakahrdaya [MH-V] and the Tarkajvāla auto-commentary [TJ-V]. This chapter of the Madhyamakahrdaya consists of a total of twenty-nine kārik $\bar{a}$-verses and, in the Tarkajvāla $\bar{a}$, he comments on each verse to various degrees of detail. ${ }^{11}$ Unfortunately, only the last two verses, i.e. MH-V 28-29, are extant on fol. 19a of the presently available Sanskrit manuscript. This is due to the fact that the manuscript of the Madhyamakahrdaya that has so far been available lacks the corresponding folio 18 which must have contained all the other 27 verses of this chapter. ${ }^{1}$

Before embarking on my discussion of the two-finger illustration, let me briefly reiterate the structure and content of the TJ-V (cf. He 2011, p. 23): the chapter starts with a lengthy introductory remark in prose in which Bhāviveka surveys the theories of the Vaiśeșika by focusing on the characteristics of the attman, the six padarthas and liberation (moksa). This is followed by the purrvapaksa which consists of but one verse, $\mathrm{MH}-\mathrm{V} 1$, which only covers the Vaiśeșika theory of liberation and is almost free of any Buddhist colouring. MH-V 2-28, form the uttarapakșa part, that is, Bhāviveka's critique, and mainly focuses on the problems surrounding the relationship between the qualities or attributes (gunas), the mind (manas) and the atman [MH-V 214], the existence of the atman per se [MH-V 15-22], and liberation [MH-V 23-28]. $\mathrm{MH}-\mathrm{V} 29$, concludes that the Vaiśeșika view is erroneous.

The two-finger illustration or example occurs a total of five times in the TJ-V, once in the introductory portion of the text, and four times in the concluding part at the end of the chapter. It is worth mentioning that the two-finger illustration does not

\footnotetext{
${ }^{11}$ For the Tibetan texts of MH-V and TJ-V, see He (2013, pp. 536-601).

${ }^{12}$ For the Sanskrit manuscript, see Jiang (1991) and Bahulkar (1994).
} 
appear in Bhāviveka's other works, that is, not in the Prajñapradīpa or in the *Hastaratna. We first come across this illustration in the introductory portion of $\mathrm{TJ}-\mathrm{V}$; there we read (cf. He 2013, p. 542):

rdzas [rnams] ni rdzas kyi bya ba ste / ji ltar sor mo gnyis bzhin no //

Substances are the effect of substance[s], just like the two-finger. ${ }^{13}$

Although he did rightly translate the sor mo gnyis as 二指 in Japanese, Y. Miyasaka, the first translator of the TJ-V in its entirety, only mentioned that this illustration was not found in the text of the Vaiśeșikasūtra that was available to him (see Miyasaka 1954; 1958). Of course, it is a pity that Candrānanda's Vrrtti was as yet unpublished and that, for the text of the Vaiśesikasütra, he could only refer to Śamkara Miśra's (14th-15th century) Upaskāra. ${ }^{1 \dot{4}}$ At the same time, he suggested that the first half phrase rdzas [rnams] ni rdzas kyi bya ba ste was a quotation from VS-U 1.1.10:

\section{dravyāṇi dravyāntaram ārabhante guṇāś ca guṇāntaram//}

Substances form another substance, and qualities form another quality.

Meanwhile, Y. Miyasaka also mentioned vs-U 1.1.23, 1.1.9, and 1.1.8, as references for this Tibetan sentence. ${ }^{15}$

In fact, VS-U 1.1.10, corresponds to two sütrapāthas in the Candrānandavrtti, i.e. VS-C 1.1.8 and 1.1.9, where read:

VS-C 1.1.8: dravyāṇi dravyāntaram ārabhante//

Substances form another substance.

VS-C 1.1.9: guṇāśs ca guṇāntaram//

And qualities [form] another quality.

Candrānanda's commentary on VS-C 1.1.8, is quite illuminating, but he does not give any illustration or simile / metaphor to further explain the theory of dravya's

${ }^{13}$ Miyasaka (1958,p. 63): もろもろの実体は、実体の原因である。たとえば、二指の 如きである. Y. Miyasaka seems to have changed Tibetan bya ba , "effect", into byed pa, "cause" (原因). Strictly speaking, the Tibetan meaning of "substances are the effect of a substance" does not match the Vaiśeșika's dravya theory which must be that "a substance is the effect of substances", or as Y. Miyasaka translated "substances are the cause of a substance". This probably is the reason why Y. Miyasaka changed the text and gave an understandable translation. However, if we delete the impossible rnams, we would get a perfect Tibetan quatrain of $4 \times 7$ syllables.

${ }^{14}$ For the Upaskāra, see Panchānana (1861), Gough (1873) and Sinha (1923). The text of the Upaskära (VS-U) that is taken from Sinha (1923) is numbered according to the sütrapāthas, so that I will not repeat the page numbers of Sinha (1923).

${ }^{15}$ VS-U 1.1.23: dravyānāạn dravyam kāryam sāmānyam // [= VS-C 1.1.22]; VS-U 1.1.9: dravyagunayoh sajātīyārambhakatvam sādharmyam// [absent in VS-C]; VS-U 1.1.8: sad anityam dravyavat kāryạ̣ kāraṇam sāmānyaviśeșavad iti dravyaguṇakarmaṇām aviśeșaḥ// [= vS-C 1.1.7]. 
origination. ${ }^{16}$ Moreover, the quoted Tibetan sentence in the TJ-V seems to be closer to VS-C 1.1.8, than to VS-U 1.1.10, which refers to both dravya and guna, for the theory of guna's origination and its descriptive illustration are given in the succeeding phrase of TJ-V. The first half of the latter phrase is in fact a verse-paraphrase of VS-C 1.1.9; it reads:

yon tan las yon tan 'byung ste //

ji ltar gzugs las gzugs bzhin no //

Quality [or: Qualities] arise from quality [or: qualities],

Just like color[s] from color[s].

On the other hand, M. Hattori suggested that rdzas [rnams] ni rdzas kyi bya ba ste was a quotation of VS-C 1.1.22 (Hattori 1994, p. 702): ${ }^{17}$

dravyāṇām dravyam kāryam sāmānyam//

A substance is the collective effect of substances.

VS-C 1.1.22, is commented on by Candrānanda as:

CV ad VS 1.1.22: sajātīyānām dvayor babhūnām vā dravyāṇām dravyam tantūnām iva pațậ samānam kāryam/

A substance is the collective effect of two or many substances that belong to the same genus, just like one cloth is the collective effect of threads.

Without the word sammanyam, VS-C 1.1.22 would match perfectly with the Tibetan rdzas [rnams] ni rdzas kyi bya ba ste. Regrettably, M. Hattori did not point out (or may not have been aware) that it occurs there together with a rather opaque and inscrutable illustration, i.e., as dvyangula or, in Tibetan garb, as sor mo gnyis.

This two-finger illustration in the TJ-V is not really understandable by the above references and Y. Miyasaka and M. Hattori seem to have ignored it. In this connection, I located two passages that contain the term / illustration dvyangula in Candrānanda's Vrtti that should now be taken into consideration in order not only to understand the unexpected sor mo gnyis, but also the theory of origination of dravya and guna as recorded in the TJ-V. In the Vaiśeșika theory of dravya if you press together two fingers (i.e. substances), the result is considered to be a new substance, namely, a two-finger. We read:

\section{VS-C 1.1.11: kāryāvirodhi dravyaṃ kāraṇāvirodhi ca/l}

A substance is not incompatible with its effect, nor it is incompatible with its cause.

${ }^{16}$ See CV ad vs 1.1.8: drvaye ca dravyānini ceti vigrahād ekamanārambhakam/ samavāyikāranāni dravyāṇi svātmavyatiriktam kāryadravyam ārabhantel ākāśādy antyāvayavidravyāṇi tu dravyam nārabhantel tulyajātīyānām mūrtikriyārūpādimatām dvayor bahūnām vā kāranānā̄m kāryārambhakatvāt/ na caivamvidhānyākāśädīni/ manaso 'sparśavattvād dravyākāraṇatvam antyāvayavidravyānām cādrșțatvāt/.

${ }^{17}$ The corresponding VS-U 1.1.23 presents the exact same Sanskrit. 
CV ad VS 1.1.11: ...tathāhy añgulidravyam kāryam dvyañgulạ̣ janayisyat tadarthena karman̄ā tatkrtena samyogena tato jātena dvyangulena na virudhyate nāpi samavāyyasamavāyikāraṇābhyām parvatatsaṃyogābhyām vāal...

...For instance, when the substance finger is about to produce the effect two-finger, it is not annihilated by the appropriate movement, nor by the connection [of the two fingers] resulting from it, nor by two-finger produced by that; neither is [the finger incompatible] with its material and non-material cause, i.e. its phalanges and their connection...

VS-C 7.1.16: kāraṇabahutvāt kāraṇamahattvāt pracayaviśeșāc ca mahat //

Because of the multiples of cause, the greatness of cause, and the special accumulation, the great (size of a thing) [originates].

\section{CV ad VS 7.1.16: dvyan்ule kārañāngulimahattvam mahattvam karoti/}

...In the two-finger, the greatness of each [single] finger as the cause produces the greatness [of the two-finger].

Be that as it may, Bhāviveka adopted the expression dvyangula of $\mathrm{CV}$ ad VS 1.1.11, to explain the genesis of dravya, i.e. rdzas [rnams] ni rdzas kyi bya ba ste. Thus, the illustration that follows, namely, ji ltar sor mo gnyis bzhin no, could be understood as follows: A substance is the effect of substances, just like the two-finger [i.e. a new substance] is the effect of two single fingers [i.e. substances].

In other words, the two-finger (dvyangula, sor mo gnyis) indicates an independent substance that is generated by two different single fingers. It is of course true that the illustration of cloth and threads given in CV ad VS 1.1.22 is more helpful in understanding the proposition: "A substance is the [collective] effect of substances, just like one cloth is the [collective] effect of threads". Besides, according to CV ad VS 1.1.11, each single finger is the inherent or material cause for producing the effect of the twofinger, namely, the fingers or phalanges are the material cause of the new two-finger.

It is noteworthy that prior to the phrase rdzas [rnams] ni rdzas kyi bya ba ste, the TJ-V contains nine continuous sentences directly quoting or paraphrasing the Vaiśeșikasütra, that is, the nine Tibetan phrases perfectly match VS-C 1.1.8 12, 14 17, ${ }^{18}$ by which the theory of six padārtha, especially the different characteristics (vaidharmya) of dravya, guna and karma are introduced. Among them, VS-C 1.1.8 9 is cited and rendered into Tibetan as:

de bzhin du rdzas kyis ni rdzas gzhan rtsom par byed la yon tan gyis kyang yon tan gzhan rtsom par byed do //

Likewise, substance[s] create[s] another substance, and quality [qualities] create[s] another quality.

${ }^{18}$ These parallel passages have been pointed out by Miyasaka (1954), Hattori (1994), and He (2013, pp. 145-157) to different degrees. 
Since it is unlikely that the same sütrapātha is quoted in one short passage, I am inclined to suggest that Tibetan rdzas [rnams] ni rdzas kyi bya ba ste is derived from VS-C 1.1.22, and not from 1.1.8. Thus, I would agree with M. Hattori, although, indeed, absence of the term sāmānyam seems to be a bit awkward here.

Some additional remarks should be made on the colour illustration that is used to describe the origination of guna - ji ltar gzugs las gzugs bzhin no -, which is close to the theory that Candrānanda provides in VS-C 1.1.9 (guṇās ca guṇāntaram) as follows:

\section{CV ad Vs 1.1.9: ...yathā tanturūpādayah svāśrayasamavete pațadravye rūpādigun̄ān ātmavyatiriktān ārabhante/}

...For example, colours etc. [qualities] of threads cause colours etc. qualities which are different from themselves in the cloth-substance which is inherent in their substratum.

Taking VS-C 1.1.9, together with Candrānanda's Vṛtti on it, it is reasonable to consider that they are the source of the theory of origination of guna that is reported by Bhāviveka in the TJ-V as yon tan las yon tan 'byung ste / ji ltar gzugs las gzugs bzhin no//. In other words, this colour illustration in the TJ-V is a nod in the direction of the Candrānandavrtti just like the case of the two-finger illustration. Indeed, this kind of colour illustration is absent from Praśastapāda's Padārthadharmasaṃraha and the *Daśapadārthī, which is only available in a Chinese translation Shengzong shijuyi lun 勝宗十句義論, both of which were most probably composed before the $\mathrm{TJ}-\mathrm{V} ;{ }^{19}$ the date of $\mathrm{TJ}-\mathrm{V}$ will be discussed later in this essay.

Active some nine to ten centuries after Bhāviveka's floruit, Śạnkara Miśra seems to be unaware of the term dvyangula when he was compiling and writing his Upaskāra. Quite mindful that there was no commentary of the Vaiśeșikasütra at his disposal and that the sütra in toto was often flawed and defective - we learn this from his introductory verse - Śamkara Miśra complained about the problems of studying the Vaiśeșikasütra in the 15th century (see Sinha 1923, p. 1). True, the term dvyanuka (two-atom / the diad) does occur in the above-mentioned available Vaiśeșika works, that is, the Candrānandavrtti, the Padārthadharmasamgraha, the *Daśapadārthī, and Bhaț̣avādīndra's Bhāṣya etc., let alone huge numbers of commentaries and subcommentaries on the Padārthadharmasamgraha, but all instances of dvyanukas are definitely used in quite dissimilar ways from the term dvyangula. Since the notion of dvyangula (two-finger) in the theory of dravya's ontogenesis is not found in other Vaiśeșika works known to me, it seems clear that its use as an illustration began and ended with Candrānanda. This leads me to conjecture that Bhāviveka understood the two-finger illustration as part and parcel of the Vaiśeșika theory of dravya [and guna], which he appears to have arrived at by summing up several of Candrānanda's comments on the relevant sütrapāthas, such as VS-C and CV ad Vs 1.1.8 9, 1.1.11 and 1.1.22, etc.

${ }^{19}$ For the Padārthadharmasamgraha, see Dube (1919), Kavirāj-Shāstri (1930), Jetly (1971), Jhā (1982), and Dvivedin (1984); for the *Daśapadārthī, see Miyamoto (1996; 2007). 


\subsection{The Two-finger Illustration in the Closing Verses of TJ-V}

The final portion of TJ-V consists of fifteen closing verses that do not explicitly comment on MH-V 29, or on MH-V in general. These verses in fact once again represent and counter-argue the theories of the Vaiśeșika in general, but the Tibetan text is often not altogether intelligible. There are indeed a lot of problems with these verses, and here I am focusing on the two that contain the two-finger illustration, even if Bhāviveka once again has nothing special or particularly informative to say about this expression in his comments.

In the context of this closing part that ends up the entire chapter TJ-V, the twofinger seems to be better called a metaphor, but not an illustration, because of its ambiguity; the quoted verses state:

sor mo gnyis las gzhan gyur pa'i //

sor gnyis zhes bya gzhan yod na //

ngos na gnas pa gcig nyid las //

gzhan pa'i sor mo gnyis mi dmigs //

de yi phyed ni der yod pa //

ma yin yin na phyed gnyis ${ }^{1)}$ 'gyur //

sor mo de gnyis ${ }^{2)}$ kyi phyed bas ${ }^{3} / /$

des na phyed sor ${ }^{4)}$ 'jug ma yin //

${ }^{1)}$ DC: ins. $m i ;{ }^{2)} \mathrm{PNG}$ : nyid; ${ }^{3)} \mathrm{PNG}$ : pas; ${ }^{4)} \mathrm{PNG}$ : por.

It is true that I did not understand the Tibetan expressions sor mo gnyis, sor gnyis, and sor mo de gnyis for a long time. Having conducted a search in the searchable texts of tbrc.org, ${ }^{20}$ they often occur in the Tibetan canonical literature, but not once in the same context of Vaiśeșika theory. Before making an attempt at translating these verses, let us first attend to the text of Candrānanda's Vrtti in which the dvyangula (two-finger) is discussed.

The other three passages in the Candränandavrtti that contain dvyaingula are the following:

VS-C 1.1.15: dravyāśrayy agunavān samyogavibhāgeșv akāraṇam anapekșa iti guṇalakșanam //

The defining features of quality: its substrate is a substance, has no quality, and independently is not the cause of conjunction or separation.

$\mathrm{CV}$ ad Vs 1.1.15: ...tathāhi / añgulyor ākāśasamyogo dvyan்ulākāśasamyoge kartavye dvyangulotpattim apekșate/ angulyoh parasparavibhāgo dvyañguāāáśavibhāgam prati kāryavināśam apekșate /...

${ }^{20}$ I would like to express here my appreciation to the Tibetan Buddhist Resource Center (tbrc.org) for the searchable Bka' 'gyur [dpe bsdur ma] and Bstan 'gyur [dpe bsdur ma]. 
...For instance, the conjunction of two fingers with space depends on the occurrence of the two-finger, when the conjunction between the twofinger and space occurs. The separation between two fingers depends on the destruction of the effect [i.e. the two-finger], when the separation between the two-finger and space occurs ....

VS-C 7.2.10: anyatarakarmaja ubhayakarmajaḥ saṃyogajaś ca saṃyogaḥ//

Conjunction is originated from the movement of either one, originated from the movement of both, and originated from conjunction.

CV ad VS 7.2.10: ...saṃyogajaḥ kāraṇākāraṇayoh samyogāt kāryākāryagataḥ yathānigulyākāśasamyogābhyām dvyañgulākāśasamyogaḥ/

...[Conjunction] that originated from conjunction is between an effect and a non-effect [i.e. unchanging substance], because of the conjunction of the cause and the non-cause [i.e. the unchanging substance], just like the conjunction of the two-finger and space, because of the conjunction of each [single] finger (i.e. two fingers) and space....

VS-C 7.2.11: etena vibhāgo vyākhyātah̆//

Separation is explained by it [i.e. VS-C 7.2.10].

$\mathrm{CV}$ ad VS 7.2.11: ...vibhāgajas tu àngulyor anyonyavibhāgād vinaștamātre dvyangule 'ngulyākāśavibhāgah kāraṇākāraṇayor vā hastākāśayor vibhāgāe charīrākāśavibhāgaḥ/ ${ }^{21}$

... On the other hand, [separation] that originated from separation is that because of two fingers' separation between each other, when the twofinger has just been destructed, there is the separation of each [single] finger and space. Or because of [the separation] of the cause and the non-cause, i.e. hand and space, there is the separation of the body and space.

According to the Vaiśeșikasütra etc. and the classical literature, many relations are considered qualities (gunas), for instance, in VS-C 1.1.5, ${ }^{22}$ conjunction (samyoga) and separation (vibhāga) are two of seventeen different kinds of gunas. Also the pervasive substances (such as space, time and soul) are said to be in contact with spatially limited substances. One characteristic of a dravya is that it has guna(s), while guna and karma cannot have guna as their characteristics. ${ }^{23}$ Therefore, both conjunction

${ }^{21}$ It is noteworthy that Padārthadharmasamgraha contains a phrase that reads: aingulyāk $\bar{a}-$ śavibhāgāe charīrākāśavibhāgavat /, see Bronkhorst-Ramseier (1994, p. 35).

${ }_{22}^{2}$ VS-C 1.1.5: rüparasagandhasparśāh sañkhāh parimānāni prithaktvam samyogavibhāgau paratvāparatve buddhayah sukhaduhkhe icchādveșau prayatnaś ca guṇạh// [= VS-U 1.1.6]

${ }^{23}$ Cf. vS-C 1.1.14 16: kriyā̄vad gunavat samavāyikāranam iti dravyalakșanam// dravyāśrayy agunavān samyogavibhāgeșv akāraṇam anapekșa iti guṇalakșanam// ekadravyam aguṇam samyogavibhāgeșv anapekșam kāraṇam iti karmalakșaṇam// [= VS-U 1.1.15 17] 
and separation are gunas that belong to the category dravya, that is, they belong to or are inherent in the two-finger (i.e. two fingers in a unit form) and/or each single finger (i.e. two fingers in separate forms) as different substances.

On the other hand, although CV ad VS 1.1.15, lists three characteristics of the guna, the illustration is used only to explain the third characteristic: samyogavibhāgeșv akāranam anapekșa, that is, "independently [guna] is not the cause of conjunction or separation". In this connection, the illustration is placed in the context of samyoga and vibhäga that are, in fact, explained separately in CV ad VS 7.2.10 and 7.2.11. ${ }^{24}$ Thus, these three illustrations are used in the similar origination theory of dravya as was reported in VS-C 1.1.11, 7.1.16, and the introductory portion of TJ-V, which have been discussed previously.

Undoubtedly, VS-C $1.1 .11,1.1 .15,7.2 .10 \sim 11,7.1 .16$, as the only sources that are available to us should be helpful to understand the curious Tibetan phrases sor mo gnyis, sor gnyis, and sor mo de gnyis in the closing verses of TJ-V. Bearing this in mind, I only very tentatively render the two previously noted, very cryptic Tibetan verses as follows: $:^{25}$

Other than two [single] fingers,

The so-called "two-finger" exists.

But for the state of oneness,

Another two-finger is not admitted. ${ }^{26}$

That [two-finger]'s part is the existence of that [i.e. each single finger], As soon as [two-finger] does not [exist], [it] becomes two parts [i.e. two

Because of that [two-]finger's two parts [i.e. each single finger], single fingers],

Therefore, half of the [two-]finger does not exist. ${ }^{27}$

It seems that these Tibetan verses refute (i.e. Bhāviveka's critique on Vaiśeșika theory) the idea of an avayavin, namely, a "whole is different from its parts", referring to the theory of its origin through samyoga and destruction through vibhāga - by using dvyangula as an example.

${ }^{24}$ The explanations of conjunction (samyoga) and separation (vibhāga) in the Padārthadharmasamgraha are more detailed, but in another way. Cf. Bronkhorst-Ramseier (1994, pp. 28 35), Kanakura (1971, pp. 150-160), and Halbfass (1992, index).

${ }^{25}$ The Japanese translation in Miyasaka (1958, p. 80) reads: 二指より他のものとなると ころの二指と名づけられる他のものがあるとき、片方にある一性〔の二指〕より他の二指 は、認められない。その半分は、そこに存しない。もし、存するならば、半分のもの〔= 二指】は二つとなる。なぜなら、その指は二つの半分だから。だからして〔二指より他の 了半分の指は認められない。This translation is not very comprehensible for me.

${ }^{26}$ Meaning that if there were another new substance of two-finger different from the two fingers, then the two fingers on the two sides - different from the two-finger unit - would not be perceived.

${ }^{27}$ Meaning that if a dvyangula (two-finger) would be a new substance, then by separating our fingers we would get two half-dvyaingulas (half-two-fingers), not two (single) fingers. Therefore, dvyangula (two-finger) cannot be admitted as a new substance different from the fingers. 
We may assume that these two verses also convey the theory of conjunction and separation in relation to substance (dravya) as in the Candrānandavrtti, though the meaning of the Tibetan texts is to be sure not as clear as Candrānanda's exposition. However, it is certain that the dvyangula (sor mo gnyis) is not a scribal error for dvyanuka (phra rab gnyis). It is thus arguably the case again that Bhāviveka was well aware of the two-finger illustration, which, again, only occurs in the Candrānanda$v r t t i$ among the few extant Vaiśeșika works of his period.

\section{On the Relative Chronology of Candrānanda and Bhāviveka}

M. Hattori presented the Tibetan text of the introductory portion of TJ-V, with the Sanskrit text of the quoted Vaiśeșikasütra in the footnotes. He compared three versions of sūtra that had been handed down: (1) the sūtrapāthas with the Candrānandavrtti, (2) Vādīndra's Vyākhyāa, and (3) Śaṃkara Miśra's Upaskāra. ${ }^{28} \mathrm{He}$ then rightly drew the conclusion that "the sütras quoted in TJ-V are close to those given in $\mathrm{VS}_{1}$ (i.e. the Candrānandavrtti)" (Hattori 1994, p. 699). At the same time, however, M. Hattori based his own translation of "the Vaiśeșika view on liberation" on the last part of the introductory portion of TJ-V, i.e. D 243b.4-244a.6 / P 274a.3-274b.6, ${ }^{29}$ and then suggested a relative chronology in which he assigned Praśastapāda to be prior to Bhāviveka, that is, to sometime between 500 and 560. It is true that, as he has pointed out, there are similar theories found in the TJ-V and the Padārthadharmasamgraha, one of which is, for instance, the idea that the apprehension of the six padārthas will lead to liberation. But this idea is not exclusive to the Padārthadharmasamgraha, for it already appeared in the Vaiśeșikasütra as such. Not only did M. Hattori himself write that "it could be ascribed to a pre-Praśastapāda Vaiśeșika, since a similar idea is already propounded in the Nyāyasütra..." (Hattori 1994, p. 706), but I also argued in one of my essays on the TJ-V that Bhāviveka's understanding of the Vaiśeșika theory of liberation was mainly derived from VS-C 5.2.20, 6.2.2 3, 6.2.12 18, which is similar or identical to VS-U 5.2.18, 6.2.2 3, 6.2.10-15, with slight differences - VS-C 6.2.14 has no parallel sütra in VS-U -, which covers most of the verses related to mokșa in the Vaiśeșikasütra. In other words, Bhāviveka did not adopt the detailed and clear explanation of dharma and adharma that we find in the Padarthadharmasamgraha,

${ }^{28}$ Vādīndra's Vyākhyā is now usually called the Bhattavādīndra-bhāsya or Tarkasāgara; see Thakur (1957; 1960 and 1985); also see Isaacson (1995, pp. 11-22). The basic and main differences of sūtrapāthas in Candrānandavrtti, Bhațtavādīndra-bhāṣya (Tarkasāgara), and Śạkara Miśra's Upaskāra can also be found in A. Thakur's introduction to Jambuvijaya (1961) and the appendices therein, and in Kanakura's studies as well, for which, see Kanakura (1971, pp. 51-52); and see also Honda (1984).

${ }^{29}$ Hattori (1994, pp. 705-706) commented on Miyasaka (1958): “...the translation (?) is quite unintelligible to me, and I could not derive any help from it for my understanding of the text." Thus, M. Hattori once more translated the last part of the introductory portion of TJ-V, i.e. the passage of the Vaiśeșika view on liberation. Regrettably, the most difficult part of the text (i.e. D 244a.13 / P 274a.7-b.2) was omitted in his translation, see Hattori (1994, p. 705). 
but rather he picked the less systematic expressions from the Vaiśeșikasūtra. Bhāviveka's primary aim was to criticise the theory of liberation by refuting the ontology of the atman and the six padārthas as propounded in the writings of the Vaiśeșika. Hence, it is not the case that only the introductory portion of TJ-V deals with the issue of mokșa. Rather, the entire chapter does so. An additional piece of evidence is that Bhāviveka's understanding of the Vaiśeșika is that for them the manas plays a crucial factor in the process of liberation. This is only attested in the Candränandavrtti and is entirely absent from the Padārthadharmasamgraha (see He 2011).

Further, Y. Miyasaka signalled long ago the existence of many parallel passages in the introductory part of TJ-V and the sütrapāthas of the Upaskāra. It is worth our while to locate and compare the entire TJ-V with the sütrapāthas from the Candrānandavrtti that was not available to Y. Miyasaka in the 1950s (see Miyasaka 1954, pp. 35-36). The numbers in the following are taken from the edition in Jambuvijaya (1961); "O" means that the very sūtrapātha from the Candrānandavrtti is most probably quoted exactly in the TJ-V; " $\Delta$ " indicates that the sütrapattha is probably quoted in part by Bhāviveka or is cited by him with some changes (cf. He 2013, pp. 343, 536601; Hattori 1994, pp. 700-702, notes 1-27):

\begin{tabular}{|l|l|l|l|l|}
\hline $1.1 .4 \circ$ & $1.1 .5 \circ$ & $1.1 .6 \circ$ & $1.1 .7 \circ$ & $1.1 .8 \circ$ \\
\hline $1.1 .9 \circ$ & $1.1 .10 \circ$ & $1.1 .11 \circ$ & $1.1 .12 \circ$ & $1.1 .14 \circ$ \\
\hline $1.1 .15 \circ$ & $1.1 .16 \circ$ & $1.1 .17 \circ$ & $1.1 .18 \Delta$ & $1.1 .19 \Delta$ \\
\hline $1.1 .22 \Delta$ & $1.1 .26 \Delta$ & $1.2 .4 \Delta$ & $1.2 .7 \circ$ & $1.2 .8 \Delta$ \\
\hline $2.1 .1 \circ$ & $2.1 .2 \circ$ & $2.1 .3 \circ$ & $2.1 .4 \circ$ & $2.1 .10 \Delta$ \\
\hline $2.1 .27 \circ$ & $2.2 .6 \circ$ & $2.2 .12 \circ$ & $2.2 .16 \circ$ & $2.2 .17 \circ$ \\
\hline $3.2 .1 \Delta$ & $3.2 .4 \Delta$ & $3.2 .5 \Delta$ & $5.2 .19 \Delta$ & $5.2 .20 \circ$ \\
\hline $5.2 .23 \circ$ & $6.2 .2 \circ$ & $6.2 .3 \Delta$ & $6.2 .12 \Delta$ & $6.2 .13 \Delta$ \\
\hline $6.2 .14 \Delta$ & $6.2 .15 \Delta$ & $6.2 .16 \Delta$ & $6.2 .17 \Delta$ & $6.2 .18 \Delta$ \\
\hline $7.1 .4 \Delta$ & $7.1 .8 \Delta$ & $7.1 .28 \circ$ & $7.1 .29 \circ$ & $7.1 .31 \Delta$ \\
\hline $7.1 .32 \Delta$ & $7.2 .2 \Delta$ & $7.2 .29 \Delta$ & & \\
\hline
\end{tabular}

It is quite conceivable that the Vaiśeșika theories reported in the TJ-V closely agree with those of the sütrapāthas of the Candrānandavrtti, the oldest Vaiśeșikasütra commentary. Or at least, it is more safe to say that Bhāviveka used as his source some unknown early sütrapāthas that are uncannily similar to those in the Candrānandavrtti. In fact, the influence of the Candrānandavrtti on Bhāviveka can be discerned from the two-finger illustration that I briefly, if all too incompletely, discussed earlier.

Although the Padārthadharmasamgraha had a far-reaching influence on later Vaiśeșika thought and is much better known than the Vaiśeșikasütra as such, it is not 
always appropriate to trace the source of the TJ-V to the Padârthadharmasamgraha by skipping over the sütrapāthas that are contained in such older commentaries as the one that issued from Candrānanda's pen. If M. Hattori could use the phrase "that the state of perfect deliverance is described in TJ-V with the expression 'just like the fire of which the fuel is burnt out' (shi zad yi me bzhin = dagdhendhanānalavat), which is found in Praśastapāda's description of the state of liberation", regardless of the similarity between the TJ-V and the VS-C, to determine that Bhāviveka was familiar with Praśastapāda's work (Hattori 1994, p. 706), then, my conjecture with respect to the two-finger illustration that indicates the probability of Bhāviveka's familiarity with Candrānanda's Vrtti, is perhaps more reliable.

On the other hand, much earlier, Y. Ejima had argued that a distinction had to be made between an original *Tarkajvāla and the text that we now have of it. The latter is only available in the Tibetan translation that came from the pens of Atiśa (982-1054) and Lo tsā ba Tshul khrims rgyal ba (1011-ca. 1070) (see Ejima 1980, pp. 1-38; and 1990; Lindtner 1982, p. 183). ${ }^{30}$ The author of the Tarkajvālā, then, must be distinguished from the one who wrote the *Tarkajvālā, the Prajñapradīpa, and the *Hastaratna. Y. Ejima's hypothesis is that this Bhāviveka was also the author of the Madhyamakārthasamgraha, and the Nikāyabhedavibhañgavyākhyāna - essentially a reproduction of the Tarkajvālā ad Madhyamakahrdaya, IV - and for him this individual flourished in the 8th century [or perhaps even later]. H. Krasser most recently re-examined the issues in connection with the Tarkajvāla and the Madhyamakärthasamgraha. He concluded that the latter contains several terms and concepts that are closely linked to Dharmakirti, whose floruit is generally accepted as of the 7 th century, even if Krasser has most recently argued for pushing his dates back by several decades into the 6th century. The main issue with the text of the Tarkajvala $\bar{a}$ as it is constituted in the Tibetan translation is that it contains a number of very pedestrian remarks concerning the logical structure of an argument that is presented in the verses of the Madhyamakahrdaya, and that it on occasion clashes with the Tibetan translation (see Krasser 2011, eps. pp. 60-71; and 2012, esp. pp. 554-556, 569ff.; and Eltschinger 1998). Weighing the evidence, Krasser quite ingeniously suggested that these could best be explained by the fact that the text of which the Tarkajvāla is a translation was compiled by a relative beginner and that this beginner possibly was a student of the author of the Madhyamakahrdaya. This obviously complicates the date of the Tarkajvālā, but even if we accepted that it was written by one or some of Bhāviveka's student(s), the text would not be much later than Bhāviveka's floruit, i.e. the 6 th to the early 7 th centuries.

${ }^{30}$ Many of us now eagerly await the retrieval and the eventual publication of the Sanskrit manuscript of the Madhyamakahrdaya that has been located in the Potala. This manuscript possibly contains the complete chapter of the Vaiśeșikatattvaviniścaya. As stated, the present copies of a manuscript of the Madhyamakahṛdaya, first photocopied by Rāhula Sānkrtyāyana and then hand copied by V. V. Gokhale, have been used for almost one hundred years. The complete manuscript of the Potala may very well shed more light on Bhāviveka and his study of the Vaiśeșika school. 


\section{Concluding Remarks}

What can be concluded, if anything, from the foregoing? I began this essay with the two-finger illustration found in the TJ-V of the 6th-century Indian intellectual Bhāviveka, where he introduces and criticises a number of Vaiśeșika positions. On the other hand, the same or at least similar two-finger illustrations only occur in Candrānanda's $V r t t i$, where, contrary to their use in the TJ-V, the intent is quite clear and understandable. Curiously, Bhāviveka nowhere mentions this illustration in his other writings. Furthermore, there are some alleged Vaiśeșika quotations in the Tarkajvāla and the * Hastarana that in fact cannot be properly traced back to the sütrapāthas or other available Vaiśeșika texts. There are also several places where Bhāviveka's understanding of Vaiśeșika thought does not altogether sit well with the early system of this school. ${ }^{31}$ Therefore my hypothesis is that Bhāviveka had written down his understanding of the theories of the Vaiśeșika at least in the following two ways:

(1) Bhāviveka quoted strictly and directly from the Vaiśeșikasūtra, more likely from the most ancient text, i.e. sütrapāthas of the Candrānadavrtti, such as VS-C 1.1.8 12, etc.

(2) Bhāviveka made some changes or additions to the sütrapäthas in order to satisfy his own requirements for his arguments and critiques. ${ }^{32}$ The two-finger illustration is such a case. We also notice that Bhāviveka appears to mix the Candrānanda's Vrtti text with the sütrapāthas per se.

Regardless of how Bhāviveka acquired his knowledge of the theories of the Vaiśeșika, his exposition should be considered one of the earliest attestations of a number of Vaiśeșika theories that prevailed among the Buddhists in around 6th-century India. The Tarkajvāla and the *Hastaratna had a definite impact on the ways in which Tibetan, Chinese, Japanese and Korean scholarship viewed non-Buddhist Indian intellectual history, and it is equally undeniable that these works exerted a fair amount of influence on how the Indian Madhayamaka tradition came to be understood in Tibet and East Asia.

To be sure, it is no easy matter to determine where we should place Candrānanda and his Vrtti in the history of Indian philosophy and the relationship of the Candrānandavrtti and Bhāviveka's writings. It will be important to compare this issue more with Bhāviveka's other major writings, especially the Prajñapradīpa and the *Hastaratna, which is a project that must be reserved for another occasion. But it is true that many expressions in the introductory portion of the TJ-V are directly or indirectly quoted from the Vaiśeșikasütra, preferably, from the presently oldest text, i.e. Candrānandavrtti. From these data, we may conjecture that Bhāvivaka or one of his students may have known the Candrānandavrtti when he was writing the Tarkajvālā.

\footnotetext{
${ }^{31}$ For additional evidence that Bhāviveka is indebted to Vaiśeșika ideas in the *Hastarana, see my "Bhāviveka's *Hastaranta on the Vaiśeșika Argument of Sound being Impermanent", which is forthcoming.

${ }^{32}$ See sūtrapāthas marked with $\Delta$ in the previous box; see also He (2011).
} 
Before more hard evidence emerges in support of Krasser's well-known hypothesis that the Tarkajvālā might have been in part written by Bhāviveka's (grand-) disciples, I would like to follow the tradition that its author was the same Bhāviveka as the author of the Madhyamakahrdaya, the *Hastaratna, and the Prajñapradipa. Thus, if this proves to be correct, then the Vaiśeșika scholar Candrānanda should be placed around 500-550, that is, he would be a junior contemporary of Dignāga and senior to Bhāviveka. In this regard, Uddyotakara and Dharmakīrti might well be considered to be contemporaneous in a broad sense as well, as was suggested by Dharmottara. My working hypothesis then is that Dignāga and Dharmakīti are at both ends of the spectrum. Between them we have, in this order, Uddoyotakara, Candrānanda and Bhāviveka. But make no mistake, this is a working hypothesis.

\section{Acknowledgments}

I would like to express here my appreciation to the peer reviewer(s) for having read ever so carefully through this essay and for having kindly indicated a number of oversights and errors that have now been corrected. Any that remain are, of course, my responsibility.

\section{Bibliographic Abbreviations}

\begin{tabular}{|c|c|}
\hline $\mathrm{CV}$ ad VS & Commentary of the Candrānandavrtti \\
\hline $\mathrm{MH}-\mathrm{V}$ & Madhyamakahrdaya $[k \bar{a} r i k \bar{a}]$ text of the Vaiśeșikatattvaviniścaya \\
\hline $\mathrm{TJ}-\mathrm{V}$ & Tarkajvālà text of the Vaiśeșikatattvaviniścaya \\
\hline $\mathrm{U} a d \mathrm{vS}$ & Commentary of the Upaskāra \\
\hline VS & Vaiśeșikasūtra \\
\hline VS-C & Sūtrapātha of the Candrānandavrtti \\
\hline VS-U & Sütrapātha of the Upaskāra \\
\hline
\end{tabular}

\section{Sanskrit Sources}

Bahulkar, S. S. (1994): The Madhyamaka-Hṛdaya-Kārikā of Bhāvaviveka: A Photographic Reproduction of Prof. V. V. Gokhale's Copy. Nagoya Studies in Indian Culture and Buddhism: Sambhāṣā Vol. 15, pp. i-iv, 1-49.

Bronkhorst, J. - Ramseier, Y. (1994): Word Index to the Praśastapādabhāsya: A Complete Word Index to the Printed Editions of the Praśastapādabhāssya. Delhi, Motilal Banarsidass Publishers.

Dube, V. P. (ed.) (1919): The Aphorisms of the Vaiseshika Philosophy by Kanāda with the Commentary of Praśastapāda, and the Gloss of Udayanācārya. Benares, Braj Bhushan Das \& Co.

Dvivedin, V. P. (ed.) (1984): The Praśastapāda Bhāșya: with Commentary Nyāyakandalī of Śrīdhara. Delhi, Sri Satguru Publications. (First printed in 1895.)

Gough, A. E. (tr.) (1873): The Vaiśeshika Aphorisms of Kanāada, with Comments from the Upaskāra of Śankara-miśra and the Vivrtti of Jaya-Nārāyaṇa-Tarkapañchānaya. London, Trübner $\&$ Co. 
Jambuvijaya (ed.) (1961): Vaiśeșikasūtra of Kaṇāda with the Commentary of Candrānanda. Baroda, Oriental Institute. (Reprinted in 1982.)

Jetly, J. S. (ed.) (1971): Praśastapādabhāṣyam: with the Commentary Kiraṇāvalī of Udayanācārya. Baroda, Oriental Institute.

Jhā, G. (tr.) (1982): Padārthadharmasangraha of Praśastapāda: with the Nyāyakandalī of Śrīdhara. Varanasi, Chaukhambha Orientalia.

Jhā, G. (tr.) (1983): The Nyāyasūtras of Gautama, with Vātsyāyana's Bhāṣya and Uddyotakara's Vārttika. Kyoto, Rinsen Book.

Jiang, Zh. (1991): Fanwen “Sizeyanjing” chaoben yingyinban 梵文《思擇焰經》抄本影印版 [A facsimile edition of the Sanskrit text of Tarkajvālāsūtra]. In: Li Zheng 李鋝-Jiang Zhongxin 蔣忠新-Duan Qing 段晴 - Qian Wenzhong 錢文忠 (eds): Ji Xianlin jiaoshou bashi huadan jinian lunwenji 季羡林教授八十華誕紀念論文集 [Papers in honour of Prof. Ji Xianlin on the occasion of his 80th birthday]. Nanchan, Jiangxi chubanshe 江西出版社, pp. $111-118$.

Kavirāj, G. N. - Shāstri, D. (eds) (1930): The Praśastapādabhāṣyam by Praśastadevācārya with Commentaries (up to dravya), Sūkti by Jagadīśa Tarkālañkāra, Setu by Padmanābha Miśra, and Vyomavatī by Vyomaśivācārya (to the end). Benares, Chowkhamba Sanskrit Series Office.

Panchānana, J. T. (ed.) (1861): The Vaiśeshika Darśana, with the Commentaries of Śankara Miśra and Jayanārāyaṇa Panchānana. Calcutta.

Ruzsa, F. (ed.) (2004/2012): Candrānanda's Commentary on the Vaiśeșika-Sūtra. https://www. academia.edu/3102869/Candrānanda_s_Commentary_on_the_Vaiśeșika-Sūtra.

Sinha, N. (1923): The Vaiśeșika Sütras of Kaṇāda: with the Commentary of Śankara Miśra and Extracts from the Gloss of Jayanarayana. Allahabad, Pānini Office. (Second, revised and enlarged edition.)

Steinkellner, E. (1979): Dharmakīrti's Pramānaviniścayaḥ: Zweites Kapitel: Svārthānumāna. Wien, Verlag der Österreichischen Akademie der Wissenschaften. (VKSKSO, Veröffentlichungen der Kommission für Sprachen und Kulturen Süd- und Ostasiens 15.)

Tarkatirtha, T. N. - Tarkatirtha, A. - Tarkatirtha, H. (eds) (1982): Nyāyadarśanam: with Vātsyāyana's Bhāṣya, Uddyotakara's Vārttika, Vācaspati Miśra's Tātparyatīkā \& Viśvanātha's Vṛtti. Kyoto, Rinsen Book.

Thakur, A. (ed.) (1957): Vaiśeșikadaraśana of Kaṇāda with an Anonymous Commentary. Darbhanga, Mithila Institute.

Thakur, A. (ed.) (1985): Vaiśeșika-darśanam: Bhațtavādīndraracita-Vaiśeșikavārtika-Kṛṣnabhūpālaracita-Trisūtrīprakāśá’jñātakarttṛkavrttibhir vilasitam maharși-kaṇāda-praṇītam. Darbhanga, Mithila Institute.

\section{References}

Aklujkar, A. (1970): Candrānanda's Date. Journal of the Oriental Institute Vol. 19, pp. 340-341. Chemparathy, G. (1970): The İ́sara Doctrine of the Vaiśeșika Commentator Candrānanda. Rtam Vol. 1, No. 2, pp. 47-52.

Eckel, M. D. (2008): Bhāviveka and His Buddhist Opponents. Cambridge, Harvard University (Harvard Oriental Series 70).

Ejima, Y. (1980): Chūgan shisō no tenkai - Bhāvaviveka kenkyū 中観思想の展開：Bhāvaviveka 研究 [An exposition of Madhyamaka thought: a study of Bhāvaviveka]. Tokyo, Shunjūsha 春秋社. 
Ejima, Y. (1990): Bhāvaviveka/Bhavya/Bhāviveka. Indogaku bukkyōgaku kenkyū 印度學佛教學 研究 [Journal of Indian and Buddhist studies] Vol. 38, No. 2, pp. 98-106.

Eltschinger, V. (1998): Bhāvaviveka et Dharmakīrti sur āgama et contre la Mīmāmiāā. Asiatische Studien / Études Asiatiques Vol. 52, pp. 57-84.

Frauwallner, E. (1962): Review of Muni Śrī Jambūvijayajī (ed.): Vaiśeșikasūtra of Kaṇāda with the Commentary of Candrānanda. Wiener Zeitschrift für die Kunde Süd- (und Ost-) Asiens Vol. 6, pp. $184-185$.

Halbfass, W. (1992): On Being and What There Is: Classical Vaiśeșika and the History of Indian Ontology. Albany, State University of New York Press.

Hattori, M. (1966): Studies of the Vaiśeșikadarśana (I), On the Vaiśeșikasūtra III, i, 13. Indogaku bukkyōgaku kenkȳu 印度學佛教學研究 [Journal of Indian and Buddhist studies] Vol. 14, No. 2, pp. 95-107.

Hattori, M. (1994): The Vaiśeșikasūtra as Referred to by Bhāvaviveka in his Tarkajvālā. Asiatische Studien / Études Asiatiques Vol. 48, No. 2, pp. 699-706.

He, H. (2011): Bhavya's Critique of Vaiśeșika Theory of Liberation in the Tarkajvālā. Studies in Indian Philosophy and Buddhism Vol. 18, pp. 23-37.

He, H. (2013): Zhongguan xinlun jiqi guzhu sizeyan yanjiu 《中觀心論》及其古注《思擇焰》 研究 [A study of the Madhyamakahrdayakārikā and the Tarkajvālā]. Beijing, China Social Sciences Press 中國社會科學出版社.

He, H. - van der Kuijp, L. (2014): Further Notes on Bhāviveka's Principal Oeuvre. Indo-Iranian Journal Vol. 57, No. 4, pp. 299-352.

Heitmann, A. L. (2004): Nektar der Erkenntnis, Buddhistische Philosophie des 6. Jh.: Bhavyas Tarkajvālā I-III. 26. Aachen, Shaker Verlag.

Honda, M. (1984): Vaiśeșika-sūtra genkei e no ikkōsatsu ヴァイシェーシカ・スートラ原型へ の一考察 [An observation on the original form of Vaiśeșika-sūtra]. Indogaku bukkyōgaku kenkyū 印度學佛教學研究 [Journal of Indian and Buddhist studies] Vol. 33, No. 1, pp. $37-43$.

Isaacson, H. (1990): A Study of Early Vaiśeșika: the Teachings on Perception. Unpublished M.A. dissertation. Groningen, Rijksuniversiteit Groningen.

Isaacson, H. (1995): Materials for the Study of the Vaiśeșika System. Unpublished Ph.D. dissertation. Leiden, Rijksuniversiteit te Leiden.

Kanakura, E. (1971): Indo no shizan tetsugaku インドの自然哲学 [Indian natural philosophy]. Kyoto, Heirakuji shoten 平楽寺書店.

Krasser, H. (2011): How to Teach a Buddhist Monk to Refute the Outsiders - Text Critical Remarks on Some Works by Bhāviveka. Dhīh Vol. 51, pp. 49-76.

Krasser, H. (2012): Bhāviveka, Dharmakīrti and Kumārila. In: Voegeli, F. et al. (eds): Devadattīyam: Johannes Bronkhorst Felicitation Volume. Bern, Peter Lang, pp. 535-594.

Lindtner, Ch. (1982): Adversaria Buddhica. Wiener Zeitschrift für die Kunde Südasiens Vol. XXVI, pp. 167-194.

Matilal, B. K. (1977): Nyāya-Vaiśeșika. In: Gonda, J. (ed.): A History of Indian Literature. Wiesbaden, Otto Harrassowitz.

Miyamoto, K. (1996): The Metaphysics and Epistemology of the Early Vaiśeșikas: with an Appendix Daśapadārthi of Candramati (a translation with a reconstructed Sanskrit text, notes and a critical edition of the Chinese version). Pune, Bhandarkar Oriental Research Institute.

Miyamoto, K. (2007): Daśapadārthī: An Ancient Indian Literature of Thoroughly Metaphysical Realism. Kyoto, Rinsen Book 臨川書店. 
Miyamoto, K. (2009): Vaiśeșika-sūtra - Kodai Indo no bunsekishugi teki jitsuzairon tetsugaku ヴ アイシェーシカ・スートラ——古代インドの分析主義的実在論哲学 [Vaiśeșika-sūtraanalytical realistic philosophy of ancient India]. Kyoto, Rinsen Book 臨川書店.

Miyasaka, Y. (1954): Shyōben inyō no Vaiśeșika tetsugaku setsu 清辨引用のヴァイシェーシ 力哲学説 [The Vaiśeșika philosophy quoted by Bhāviveka]. Bunka 文化 [Culture] Vol. 18, No.3, pp. 24-40.

Miyasaka, Y. (1958): Ronri no en niokeru Vaiśeșika tetsugaku 論理の炎におけるヴァイシェー シ力哲学 [The Vaiśeșika philosophy in the Tarkajvāla]. Kōyasan daigaku ronsō 高野山 大学論叢 [Journal of Kōyasan University] Vol. 1, pp. 51-87.

Nakamura, H. (1977-1978): Vaiśeșika gakuha no genten ヴァシェーシカ学派の原典 [The classics of the Vaiśeșika School]. Sankō bunka kenkyūjo nenpō 三康文化研究所年報 [Annual report of the Sankō Research Institute for the Study of Buddhism] Vols 10-11, pp. 1-156.

Nishikawa, T. (1983): Bhāvaviveka to Vaiśeșika - Prajñāpradīpa dai 19 shō nitsuite Bhāvaviveka と Vaiśeșika - Prajñāpradīpa 第19章について [Bhāvaviveka and Vaiśeșika - On the 19th Chapter of Prajñāpradīpa]. Komazawa daigaku daigakuin bukkyōgaku kenkyūkai nenpō 駒沢大学大学院仏教学研究会年報 [Annual report of studies of Buddhism, Graduate School of Komazawa University] Vol. 16, pp. 8-15.

Nozawa, M. (1993): The Vaiśeșikasūtra with Candrānanda's Commentary (1). Numazu kōgyō kōtō senmon gakkō kenkyū hōkoku 沼津工業高等専門学校研究報告 [Research reports of Numazu Technical College] Vol. 27, pp. 97-116.

Potter, K. H. (ed.) (1977): Encyclopedia of Indian Philosophies - Indian Metaphysics and Epistemology: The Tradition of Nyāya-Vaiśeșika up to Gangeśa. Delhi, Motilal Banarsidass.

Ruzsa, F. (2010): Two MSS of Candrānanda's Vrtti on the Vaiśeșikasūtra and the Errors of the Copyists. In: Bronkhorst, J. - Preisendanz, K. (eds): From Vasubandhu to Caitanya - Studies in Indian Philosophy and Its Textual History. Delhi, Motilal Banarsidass, pp. 173-183.

Saitō, A. (2005): “Chūgan shinron" no shōmei to seiritsu o meguru shōmondai『中観心論』の書 名と成立をめぐる諸問題 [Some problems with the title and formation of the Madhyamakahrdayaśāstra]. Indogaku bukkyōgaku kenkyū 印度學佛教學研究 [Journal of Indian and Buddhist studies] Vol. 53, No. 2, pp. 167-173.

Thakur, A. (1960): Bhatțavādīndra - The Vaiśeșika. Journal of the Oriental Institute Vol. 10, pp. $22-31$.

Thakur, A. (ed.) (2003): Origin and Development of the Vaiśeșika System. Delhi, Motilal Banarsidass (History of Science, Philosophy and Culture in Indian Civilization, Volume II, Part 4).

Ui, H. (1917): The Vaiśeșika Philosophy according to the Daśapadārthaśāstra: Chinese Text with Introduction, Translation, and Notes. London, Royal Asiatic Society. (Second edition in 1962.) 